\title{
Evaluation of Antagonistic Activity of Trichoderma spp. against Meloidogyne incognita
}

\author{
S. SELLAMI*, N. BENTTOUMI, S. BERRAHIA and H. BOUREGHDA \\ Laboratory of Phytopathology and Molecular Biology, Department of Botany, \\ National High School of Agronomy El-Harrach, Algeria
}

(Received: 31 January 2017; accepted: 15 May 2017)

\begin{abstract}
Root-knot nematode Meloidogyne spp. is one of the most dangerous pests on vegetable crops in Algeria. Actually, research of alternative methods against these enemies is necessary. Culture filtrates of three species of filamentous fungi, Trichoderma harzianum, T. atroviride, T. longibrachiatum, tested against Meloidogyne incognita showed a nematicide effect on larval mortality of the second stage and also inhibited the potential of hatching nematode whose effectiveness varies with species, time of exposition and concentration. Finally, the use of some of these species of fungi can be an alternative method in the management of this bioagressor.
\end{abstract}

Keywords: Filtrate culture, Trichoderma, Meloidogyne incognita, mortality, hatching, nematicide.

In Algeria, tomato is one of the most important vegetable crops and covers an area of 22497 ha with a yield of $433 \mathrm{t} / \mathrm{ha}$ (Faostat, 2014). This yield remains low compared to that of the Mediterranean countries, which is $517 \mathrm{t} /$ ha in Italy, $813 \mathrm{t} /$ ha in Spain and $922 \mathrm{t} /$ ha in Morocco (Faostat, 2014). This decrease in yield is due to several phytosanitary constraints; among these, root-knot nematodes are major pathogens in field grown tomatoes and plantation sites where they cause considerable losses in yields worldwide (Whitehead, 1998). In Algeria, this bioagressor is among the major limiting factors in the production of vegetable crops (Sellami et al., 1999). Nematicide application is the main method for controlling nematode induced diseases (Abu Gharbieh et al., 2010). However, this method presents considerable environmental risks; detrimental effect on the fauna creating an ecological vacuum and mainly deleterious effects on human health. So the development of alternative control methods is of great importance (Sahebani and Hadavi, 2008).

Indeed, the application of antagonistic microorganisms or their products (enzymes, antibiotics and toxins) can constitute an interesting research area (Meyer et al., 2004). Nematophagous fungi are very common biological control agents in soil and have been studied extensively in the world (Stirling and Mankau, 1977; Stirling, 1991). Similarly, Trichoderma spp. have been widely studied as potential biocontrol agents for controlling many plant pathogens (Agrios, 2005; Harman, 2011). Trichoderma spp. has also been described as biocontrol agents against plant-parasitic nematodes. Several reports showed that Trichoderma spp. are able to suppress Meloidogyne spp. populations and increase crop yields (Sharon et al., 2001; 2007; Sahebani and Hadavi, 2008). The aim of this study

* Corresponding author; e-mail: s.sellami@ hotmail.fr 
was to evaluate the biological potential of three isolates belonging to the three species of Trichoderma, Trichoderma harzianum Rifai, Trichoderma longibrachiatum Rifai and T. atroviride P. Karsten against Meloidogyne incognita (Kofoid and White) Chitwood. These isolates have already shown efficiency against Fusarium oxysporum f. sp. ciceris on chickpea (Boureghda and Bouznad, 2009) and Fusarium species associated with Fusarium head blight of wheat by in vitro bioassay (Boureghda and Renane, 2011).

\section{Materials and Methods}

\section{Preparation of nematodes inoculums}

The population of Meloidogyne incognita (Kofoid and White) Chitwood from the area of Staouali (Alger) is maintained and multiplied on tomato (Var. Marmande). Egg masses were maintained in Petri dishes for 24-48 hours in distilled $\mathrm{H}_{2} \mathrm{O}$ for the juvenile hatching.

\section{Trichoderma strains}

Three isolates of the antagonistic fungus Trichoderma spp. T. longibrachiatum (TL.1), T. harzianum (Th.6), and T. atroviride (Ta.13) were used in the present study. These isolates were obtained and identified by Boureghda (2009) and stored in Potato Dextrose Agar (PDA) medium in glass tubes at $4{ }^{\circ} \mathrm{C}$ at the laboratory of mycology of the Department of Botany at the High National School of Agronomy of El Harrach-Algiers (Algeria).

\section{Preparation of the fungal inoculum}

Plugs of Trichoderma strains previously stored on Potato Dextrose Agar (PDA) medium in glass tubes at $4{ }^{\circ} \mathrm{C}$ were transplanted into (PDA) plate for use for in vitro antagonism assays. Filtrate culture of Trichoderma spp. isolates was prepared according to the method described by Vinale et al. (2006), $100 \mathrm{ml}$ of potato broth (PDB = Potato Dextrose Broth medium) were inoculated by $6 \mathrm{~mm}$ diameter plugs of Trichoderma spp. culture and incubated with shaking at room temperature for 10 to 15 days.

Effect of the culture filtrates of the three strains of Trichoderma on the juveniles mortality of Meloidogyne incognita

Fifty $M$. incognita larvae (L2) of 24 to 48 hours old are placed in $5 \mathrm{~cm}$ diameter Petri dishes containing $3 \mathrm{ml}$ of the Trichoderma spp. culture filtrates at concentrations of $\mathrm{S}$ (culture filtrate) (100\%), S/2 (50\%) and S/4 (25\%). For each treatment 3 replicates were performed. The mortality rate was determined after 24, 48 and 72 hours of exposure at room temperature. The effect of Trichoderma culture filtrates on $M$. incognita larvae (L2) was compared to controls represented by larval solutions and chemical treatments based 
on two organophosphorus nematicides: Mocap (Ethoprophos) at 10\% active ingredient (Ma) $(332 \mu \mathrm{g} \mathrm{Ma} / 1$ and Nemacur at 10\% (332 $\mu \mathrm{g} \mathrm{Ma} / \mathrm{l})$ (Phenamiphos). The results are expressed as a percentage of mortality corrected according to the formula established by Abbot (1925):

Percentage of corrected mortality MC\% $=(\mathrm{M} 2-\mathrm{M} 1) /(100-\mathrm{M} 1) \times 100$ where:

M1: mortality percentage observed in control.

M2: percentage of mortality observed in the treated population.

MC: corrected mortality percentage.

Effect of culture filtrates of Trichoderma spp. on egg hatching of Meloidogyne incognita

Egg masses from infested tomato roots are placed in Petri dishes containing $3 \mathrm{ml}$ of Trichoderma spp. culture filtrate at concentrations of 25, 50 and 100\% and controls as previously described. For each treatment 4 replicates were performed. The hatching larvae were counted after 1, 2, 4 and 8 days under a binocular stereoscope. The results are expressed as percent inhibition of hatching.

\section{Statistics}

An analysis of the variance was carried out using, the STATISTCF software. The differences between the treatments for the studied parameters are compared by means of Newman-Keuls test $(\mathrm{P}<0.05)$.

\section{Results and Discussion}

Trichoderma culture filtrates induced the mortality of $M$. incognita juveniles which increases with increasing concentration and time of exposure (Table 1). Concerning the culture filtrate of $T$. longibrachiatum (TL.1), the mortality of $M$. incognita rate was low and chemical treatments are more effective than this treatment. The culture filtrate of T. harzianum (Th.6) had induced the highest mortality rates except for the low concentration (S/4) after 24 hours of exposure. This treatment induced a higher mortality rate than treatment of Nemacur but comparable to the treatment with Mocap (Table 1). For T. atroviride (Ta.13), the mortality was lower than the two nematicides (Nemacur and Mocap), its effectiveness is noted for the high (S) and S/2 concentrations after 72 hours of exposure time.

The control shows a very low mortality rate for the three periods of exposure and all treatments. Inhibition of hatching of $M$. incognita larvae by various culture filtrate concentrations is shown in (Table 2). Eight days of treatment with the culture filtrate of T. longibrachiatum (TL.1) resulted in a slight hatching inhibition compared with two nematicide treatments Nemacur and Mocap. Only its undiluted culture filtrate had a significant inhibitory effect on hatching. Concerning the culture filtrate of $T$. atroviride (Ta.13) this solution had a similar rate of hatching inhibition to that of Mocap, while Nemacur was found to be more effective. However, this activity depends on species, exposure time 
Table 1

Effects of culture filtrates of Trichoderma spp. on the mortality of $M$. incognita

\begin{tabular}{|c|c|c|c|}
\hline \multirow{3}{*}{ Treatments and exposure time ( hours) } & \multicolumn{3}{|c|}{ Mortality of M. incognita juveniles (percent of means \pm SE\%) } \\
\hline & \multicolumn{3}{|c|}{ Culture filtrate } \\
\hline & $\mathrm{S}(100 \%)$ & $\mathrm{S} / 2(50 \%)$ & $\mathrm{S} / 4(25 \%)$ \\
\hline \multicolumn{4}{|l|}{ T. longibrac hiatum $(\mathrm{Tl} .1)$} \\
\hline $24 \mathrm{~h}$ & $2.53 \pm 0.58$ & $0.5 \pm 0.58$ & $0 \pm 0$ \\
\hline $48 \mathrm{~h}$ & $7.69 \pm 2$ & $4.61 \pm 1$ & $0 \pm 0$ \\
\hline $72 \mathrm{~h}$ & $13.02 \pm 2.52$ & $6.25 \pm 2$ & $0.53 \pm 0.58$ \\
\hline \multicolumn{4}{|l|}{ Control } \\
\hline $24 \mathrm{~h}$ & $0 \pm 0$ & - & \\
\hline $48 \mathrm{~h}$ & $1.52 \pm 1$ & - & \\
\hline $72 \mathrm{~h}$ & $3.03 \pm 1$ & - & \\
\hline \multicolumn{4}{|l|}{ Nematicidal treatment (Nemacur) } \\
\hline $24 \mathrm{~h}$ & $49 \pm 2.08-$ & - & \\
\hline $48 \mathrm{~h}$ & $63.08 \pm 3.61-$ & - & \\
\hline $72 \mathrm{~h}$ & $73.44 \pm 6.08-$ & - & \\
\hline \multicolumn{4}{|l|}{ Nematicidal treatment (Mocap) } \\
\hline $24 \mathrm{~h}$ & $45.95 \pm 3.06-$ & - & \\
\hline $48 \mathrm{~h}$ & $59.48 \pm 3.51-$ & - & \\
\hline $72 \mathrm{~h}$ & $65.63 \pm 5.29$ & - & \\
\hline \multicolumn{4}{|l|}{ T. harzianum (T6) } \\
\hline $24 \mathrm{~h}$ & $56.93 \pm 4.53$ & $52.63 \pm 4.53$ & $45.94 \pm 2.50$ \\
\hline $48 \mathrm{~h}$ & $64.39 \pm 4.73$ & $57.08 \pm 6.43$ & $50.73 \pm 5.13$ \\
\hline $72 \mathrm{~h}$ & $71.79 \pm 6.56$ & $61.39 \pm 8.72$ & $53.47 \pm 4.04$ \\
\hline \multicolumn{4}{|l|}{ Control } \\
\hline $24 \mathrm{~h}$ & $0.48 \pm 0.58$ & - & - \\
\hline $48 \mathrm{~h}$ & $2.38 \pm 1.5$ & - & \\
\hline $72 \mathrm{~h}$ & $3.81 \pm 2$ & - & \\
\hline \multicolumn{4}{|l|}{ Nematicidal treatment (Nemacur) } \\
\hline $24 \mathrm{~h}$ & $58.37 \pm 4.53$ & - & - \\
\hline $48 \mathrm{~h}$ & $61.95 \pm 1.73$ & - & - \\
\hline $72 \mathrm{~h}$ & $69.81 \pm 9.29$ & - & - \\
\hline \multicolumn{4}{|l|}{ Nematicidal treatment (Mocap) } \\
\hline $24 \mathrm{~h}$ & $53.59 \pm 11.24$ & - & - \\
\hline $48 \mathrm{~h}$ & $57.08 \pm 4.16$ & - & - \\
\hline $72 \mathrm{~h}$ & $63.36 \pm 3.21$ & - & - \\
\hline \multicolumn{4}{|l|}{ T. atroviride (Ta.13) } \\
\hline $24 \mathrm{~h}$ & $35.10 \pm 2$ & $30.32 \pm 1$ & $19.68 \pm 3.79$ \\
\hline $48 \mathrm{~h}$ & $51.90 \pm 3.05$ & $43.7 \pm 1.53$ & $33.3 \pm 1.73$ \\
\hline $72 \mathrm{~h}$ & $56.94 \pm 3$ & $50.3 \pm 2.65$ & $37.42 \pm 2.31$ \\
\hline \multicolumn{4}{|l|}{ Control } \\
\hline $24 \mathrm{~h}$ & $0 \pm 0.58$ & - & - \\
\hline $48 \mathrm{~h}$ & $2.6 \pm 0.58$ & - & \\
\hline $72 \mathrm{~h}$ & $4.74 \pm 2$ & - & \\
\hline \multicolumn{4}{|l|}{ Nematicidal treatment (Nemacur) } \\
\hline $24 \mathrm{~h}$ & $54.78 \pm 7.10$ & - & \\
\hline $48 \mathrm{~h}$ & $64.48 \pm 3.61$ & - & \\
\hline $72 \mathrm{~h}$ & $72.06 \pm 7.21$ & - & \\
\hline \multicolumn{4}{|l|}{ Nematicidal treatment (Mocap) } \\
\hline $24 \mathrm{~h}$ & $35.64 \pm 3.06$ & - & \\
\hline $48 \mathrm{~h}$ & $53 \pm 1.73$ & - & \\
\hline $72 \mathrm{~h}$ & $57.54 \pm 5.03$ & - & - \\
\hline
\end{tabular}

Acta Phytopathologica et Entomologica Hungarica 
Table 2

Effect of culture filtrates of Trichoderma spp. on egg hatching of M. incognita

\begin{tabular}{|c|c|c|c|c|c|c|}
\hline \multirow{3}{*}{ Treatments } & \multicolumn{3}{|c|}{$\begin{array}{l}\text { Number of juveniles hatched after } 8 \text { days } \\
\text { of incubation (means } \pm \text { SE) }\end{array}$} & \multicolumn{3}{|c|}{ Hatching inhibition over control (\%) } \\
\hline & \multicolumn{3}{|c|}{ Culture filtrate } & \multicolumn{3}{|c|}{ Culture filtrate } \\
\hline & $\mathrm{S}$ & $\mathrm{S} / 2$ & $\mathrm{~S} / 4$ & $\mathrm{~S}$ & $\mathrm{~S} / 2$ & $\mathrm{~S} / 4$ \\
\hline T. longibrachiatum (Tl.1) & $169.5 \pm 3.70$ & $178 \pm 4.97$ & $186.55 \pm 5.89$ & 13 & 8 & 4.6 \\
\hline Control & $195 \pm 3.84$ & - & - & - & - & - \\
\hline $\begin{array}{l}\text { Nematicidal treatment } \\
\text { (Nemacur) }\end{array}$ & $82 \pm 4.32$ & - & - & 58 & - & - \\
\hline $\begin{array}{l}\text { Nematicidal treatment } \\
\text { (Mocap) }\end{array}$ & $90.75 \pm 2.75$ & - & & 54 & - & - \\
\hline T. harzianum (Th.6) & $73 \pm 4.99$ & $88 \pm 6.95$ & $118 \pm 9.70$ & 63 & 55 & 40 \\
\hline Control & $193 \pm 2.35$ & - & & - & - & - \\
\hline $\begin{array}{l}\text { Nematicidal treatment } \\
\text { (Nemacur) }\end{array}$ & $64.25 \pm 4.35$ & - & - & 67 & - & - \\
\hline $\begin{array}{l}\text { Nematicidal treatment } \\
\text { (Mocap) }\end{array}$ & $87 \pm 6.81$ & - & - & 56 & - & - \\
\hline T. atroviride (Ta.13) & $99 \pm 6.52$ & $158 \pm 5.29$ & $109.5 \pm 2.19$ & 57 & 52 & 31 \\
\hline Control & $228 \pm 3.32$ & - & - & - & - & - \\
\hline $\begin{array}{l}\text { Nematicidal treatment } \\
\text { (Nemacur) }\end{array}$ & $88 \pm 6.18$ & - & - & 62 & - & - \\
\hline $\begin{array}{l}\text { Nematicidal treatment } \\
\text { (Mocap) }\end{array}$ & $102 \pm 6.95$ & - & - & 55 & - & - \\
\hline
\end{tabular}

and concentration. Based on our data, the two isolates of Trichoderma species T. harzianum (Th.6) and T. atroviride (Ta.13) recorded significant larval mortality rates and inhibition of egg hatching with all three concentrations tested against Meloidogyne incognita and among these two species, T. harzianum was the most effective.

These results are in agreement with those recorded by Dababat and Sikora (2007), who reported the efficacy of $T$. harzianum and $T$. viride on the mortality of second stage larvae (L2) of M. incognita and found that T. harzianum was more effective than other Trichoderma species tested. Similarly, Naserinasab et al. (2011) reported 84\% eggs parasitism of $M$. javanica by $T$. harzianum. A reduction in the number of $M$. incognita larvae and a $69.79 \%$ reduction in root galls were observed by the use of a commercial bioproduct based on T. harzianum (Radwan et al., 2012). Likewise, Mendoza et al. (2013) reported the nematicidal activity of T. atroviride, T. harzianum and $T$. viride on the development of Meloidogyne spp. under laboratory conditions.

Under our experimental conditions, the culture filtrate of T. longibrachiatum was nearly ineffective, which probably due to the variability of isolates, does not correspond to the results of Al-Shammari et al. (2013) who recorded a percentage of mortality of $64.5 \%$ against $M$. javanica juveniles after 72 hours of exposure. The nematicidal activity of Trichoderma strains is probably attributed to the compounds present in the culture filtrates of the strains tested. Indeed, these compounds are volatile or non-volatile secondary 
metabolites with biological effects. Thus, according to the Sharon et al. (2001), this nematicidal activity can be attributed to several mechanisms of action. Among which there is competition for nutrients, antibiosis or the production of specific enzymes of cell wall degradation such as chitinases or proteases. In addition, these fungi may also promote plant growth and induce systemic resistance of plants (Sahebani and Hadavi, 2008).

Compared to Mocap a higher effectiveness of Nemacur was observed during our experiment, probably due to the reversibility of the action of Mocap, which has a nematostatic effect. Indeed, among the organophosphorus nematicides Mocap exhibits high reversibility, so the surviving nematodes can develop and multiply (Bunt, 1979).

Finally, the results of this study are promising and encouraging and it would be recommended to investigate further the applicability of Trichoderma spp. because their metabolites produced of great interest for their potential exploitation of biopesticides considering that the use of chemicals against these pests is increasingly limited.

\section{Literature}

Abbot, W. S. (1925): A method for computing the effectiveness of an insecticide. J. Ecol. Entomol. 18, $265-267$. Abu Gharbieh, W., Hamdi, Z. A., Al-Yahia, F. A. and Sellami, S. (2010): Development of phytonematology. In: A. S. Al Hamzi, Z. A. Stephan and A. Dawabah (eds): Plant Parasitic Nematodes in Arab Countries. Dar Wael, 1st ed. Vol. 1. Jordan, 586 p.

Agrios, G. N. (2005): Plant Pathology. Elsevier Academic Press, 5th ed. Burlington, MA, 922 p.

Al-Shammari, T. A., Bahkali, A. H., Elgorban, A. M., El-Kahky, M. T. and Al-Sum, B. A. (2013): Use of Trichoderma longibrachiatum and Mortierella alpine against root knot nematode, Meloidogyne javanica on tomato. J. Appl. Microbiology 7, 199-207.

Boureghda, H. (2009): Recherche de l'effet antagoniste de Trichoderma spp. à l'égard de Fusarium oxysporum f. sp. Ciceris (Padwick) Matuoet K. Sato $(F o c)$, agent du flétrissement du pois chiche. Thèse de doctorat en Sciences Agronomiques. Institut National Agronomique. El Harrach, Alger, 153 p.

Boureghda, H. and Bouznad, Z. (2009): Biological control of Fusarium wilt of chickpea using isolate of Trichoderma atroviride, T. harzianum and T. longibrachiatum. Acta Phytopathol. et Entomol. Hung. 44, 25-38.

Boureghda, H. and Renane, R. (2011): In vitro study of antagonistic activity of some isolates of Trichoderma spp. against Fusarium spp. isolates causal agent of head scab of wheat. Arab J. Plant Protection, 29, 51-59.

Bunt, J. A. (1979): Effect and mode of action of the nematicide ethoprophos. Meded. Fac. Landbouwwet. Rijksuniv. Gent, 44, 357-366.

Dababat, A. A. and Sikora, R. (2007): Use of Trichoderma harzianum and Trichoderma viride for the biological control of Meloidogyne incognita on tomato. Jordan J. Agric. Sci. 3, 297-309.

Faostat (2014): Statistiques de la FAO http://faostat.fao.org/site/567/default.aspx\#ancor

Harman, G. E. (2011): Trichoderma not just for biocontrol anymore. Phytoparasitica 39, 103-108.

Mendoza, G. A. T., Wilson, J. H. and Colina, J. C. (2013): Efecto de Trichoderma atroviride, Trichoderma harzianum, Trichoderma virides obrehuevos de Meloidogyne sp. encondiciones de laboratorio. Rebiolest 1, $65 \mathrm{p}$.

Meyer, S. L. F., Huettel, R. N., Liu, X. Z., Humber, R. A., Juba, J. and Nitao, J. K. (2004): Activity of fungal culture filtrates against soybean cyst nematode egg hatch juvenile mortality. Nematology 6, 23-32.

Naserinasab, F. N., Sahebani, R. N. and Etebarian, H. R. (2011): Biological control of Meloidogyne javanica by Trichoderma harzianum BI and salicylic acid on tomato Rican. J. Food Sci. 5, 276-280.

Radwan, M. A., Farrag, A. A., Abu-Elamayem, M. M. and Ahmed, N. S. (2012): Biological control of the rootknot nematode, Meloidogyne incognita on tomato using bio products of microbial origin. Appl. Soil Ecology 56, 58-62. 
Sahebani, N. and Hadavi, N. (2008): Biological control of the root knot nematode Meloidogyne by Trichoderma harzianum. Soil. Biology and Biochemistry 40, 2016-2020.

Sellami, S., Lounici, M., Eddoud, A. and Benseghir, H. (1999): Distribution et plantes hôtes associées aux Meloidogyne sous abri plastique en Algérie. Nematologie Meditérranéenne 27, 295-301.

Sharon, E., Bar-Eyal, M., Chet, I., Herrera-Estrella, A., Kleifeld, O. and Spiegel, Y. (2001): Biological control of the root-knot nematode Meloidogyne javanica by Trichoderma harzianum. Phytopathology 91, 687-693.

Sharon, E., Chet, I., Viterbo, A., Bar-Eyal, M., Nagan, H., Samuels, G. J. and Spiegel, Y. (2007): Parasitism of Trichoderma on Meloidogyne javanica and role of the gelatinous matrix. European J. Plant Pathol. 118, 247-258.

Stirling, G. R. (1991): Biological Control of Plant Parasitic Nematodes. CAB International, Wallington, UK, 28 p.

Stirling, G. R. and Mankau, R. (1977): Biological control of nematode parasites of citrus by natural enemies. Proc. of the International Society of Citriculture 3, 843-847.

Vinale, F., Marra, R., Scala, F., Ghisalberti, E. L., Lorito, M. and Sivasithamparam, K. (2006): Major secondary metabolites produced by two commercial Trichoderma strains active against different phytopathogens. Letters in Appl. Microbiol. 43, 143-148.

Whitehead, A. G. (1998): Sedentary Endoparasits of Roots and Tubers Meloidogyne and Nacobbus in Plant Nematode Control. C.A.B. International London, 384 p. 
